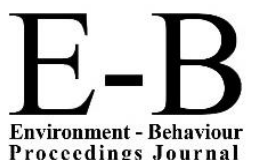

Environment - Behaviour
AIVCE-BS-2, 2020ShahAlam

https://www.amerabra.org; https://fspu.uitm.edu.my/cebs; https://www.emasemasresources.com/ AMEABRA International Virtual Conference on Environment-Bahaviour Studies, $2^{\text {nd }}$ Series CE-Bs, FSPU, Universiti Teknologi MARA, Shah Alam, 02-03 Dec 2020

\section{e-IPH}

e-Internationa Publishing House Ltd United Kingdom

\title{
Intensifying Focus on Service Quality in Higher Education Institutions: Emotional and Spiritual Intelligence
}

\author{
Mazni Saad ${ }^{1}$, Norliana Ahmadshah², Kamisah Supian³, Anita Abdul Rani ${ }^{4}$ \\ 1Department of Tourism, Kulliyah of Languages and Management, International Islamic \\ University Malaysia, Pagoh Edu Hub, Muar, Johor, Malaysia \\ 2Department of Management Information Systems and Business Analytics, Faculty of Business and Accountancy, \\ Universiti Selangor, Shah Alam, Selangor, Malaysia \\ ${ }^{3}$ Department of Muamalat and Marketing, Faculty of Business and Accountancy, \\ Universiti Selangor, Shah Alam, Selangor, Malaysia \\ ${ }^{4}$ Centre of Human Sciences, \\ Universiti Malaysia Pahang, Pekan, Pahang, Malaysia
}

maznisaad@iium.edu.my; norliana@unisel.edu.my; kamisah@unisel.edu.my; anita@ump.edu.my

Tel: +6017-8787543

\begin{abstract}
The influence of Emotional and Spiritual Intelligence was investigated on the lecturers' Service Quality. Based on stratified sampling method, the results confirmed that both types of intelligence have a positive and significant influence on the lecturers' teaching progression. In conclusion, if the average level of each intelligence was good, then the level of Service Quality would also excel accordingly. The study highlights the need to have both EQ and $\mathrm{SQ}$ as it will encourage and motivate them into giving their best service to the university as well as their highest commitment towards giving students the best quality learning experience.
\end{abstract}

Keywords: Emotional Intelligence; Higher Education Institutions; Service Quality; Spiritual Intelligence

eISSN: 2398-42870 2020. The Authors. Published for AMER ABRA cE-Bs by e-International Publishing House, Ltd., UK. This is an open access article under the CC BYNC-ND license (http://creativecommons.org/licenses/by-nc-nd/4.0/). Peer-review under responsibility of AMER (Association of Malaysian Environment-Behaviour Researchers), ABRA (Association of Behavioural Researchers on Asians) and CE-Bs (Centre for Environment-Behaviour Studies), Faculty of Architecture, Planning \& Surveying, Universiti Teknologi MARA, Malaysia.

DOI: https://doi.org/10.21834/ebpj.v5i15.2340

\subsection{Introduction}

Quality of life of academicians determines the service quality in higher education institutions (HEls). The academicians are expected to have strong faith, fully integrated, holistic, and well balanced to be fully functioning in producing the best outputs. All universities in Malaysia are undergoing a transformation process outlined in the 2015-2025 Malaysian Education Blueprint. In one of the ten shifts is talent excellence that aims to develop and nurture academics. The blueprint also contains a New Academia Talent Framework (NATF) model that highlights the government's intention of creating holistic academics by setting up high-quality tertiary education. A highquality education is only deemed possible when the quality of its academic community is also very high. To assess academic excellence, the Ministry of Higher Education (MOHE) has placed a university rating protocol and introduced the Malaysian Quality Evaluation System (MyQUEST) specifically for private colleges to raise its degree of competitiveness through continuous improvement capacity building. The other metric rating, known as SETARA, focuses on assessing items, as shown in Table 1. In 2017, International Medical University,

eISSN: 2398-4287C 2020. The Authors. Published for AMER ABRA cE-Bs by e-International Publishing House, Ltd., UK. This is an open access article under the CC BYNC-ND license (http://creativecommons.org/licenses/by-nc-nd/4.0/). Peer-review under responsibility of AMER (Association of Malaysian Environment-Behaviour Researchers), ABRA (Association of Behavioural Researchers on Asians) and cE-Bs (Centre for Environment-Behaviour Studies), Faculty of Architecture, Planning \& Surveying, Universiti Teknologi MARA, Malaysia.

DOI: https://doi.org/10.21834/ebpj.v5i15.2340 
Monash University Malaysia, Universiti Kebangsaan Malaysia, Universiti Malaya, Universiti Putra Malaysia, Universiti Sains Malaysia, Universiti Teknologi Malaysia, and Universiti Teknologi Petronas obtained the outstanding 6-star SETARA.

Aimed to intensify focus on service quality in higher education institutions, this research is guided by a two-fold research question: (1) Do EQ and SQ matter for Service Quality and (2) If yes, which type of intelligence has a significant difference on Service Quality?

Table 1: Indicators and Weightage of SETARA-2017

\begin{tabular}{lccc}
\hline & \multicolumn{3}{c}{ Category of Institution } \\
\hline Instrument & Mature University & Emerging University & University College \\
\hline General & $40 \%$ & $40 \%$ & $40 \%$ \\
Teaching \& Learning & $30 \%$ & $40 \%$ & $50 \%$ \\
Research & $20 \%$ & $15 \%$ & $5 \%$ \\
Services & $10 \%$ & $5 \%$ & $5 \%$ \\
\hline \multicolumn{4}{c}{}
\end{tabular}

\subsection{Literature Review}

\subsection{Emotional Quotient and Service Quality}

The ability to express and control individual emotions is essential and personal ability to understand, interpret, and respond to others' emotions. Psychologists refer to this ability as emotional quotient (or intelligence) (EQ), and some professionals even endorse that it can be greater essential than the intelligence quotient (IQ) in individual normal success in life. Mayer and Salovey (1993) define EQ as the ability to monitor one's feelings and emotions to discriminate among them and use this awareness of emotions to guide one's thinking and actions. $E Q$, therefore, talks about the relationship between thoughts, behaviours and feelings. It can be determined as the degree to which a person can perceive, understand, and regulate other people's emotions and amalgamate their thoughts and actions (Basharat, 2013).

$E Q$ is one of the most important determinants of service quality. Thus, academics in any higher education institution must be receptive and adaptive towards the students' demands and behaviours. EQ is one of the factors that can help academics respond effectively to their students. Numerous studies show the importance of $E Q$ for service quality. There is ample evidence to show that employees with high emotional competencies are better at managing themselves and understanding customer's attitude in the service interaction (Opuni \& Adu-Gyamfi (2015). The study proved that EQ positively and significantly predicts service quality for customers and the overall image of the company will get stronger.

In HEls cases, Yen (2013) measured service quality (SERVQUAL) the Vietnamese students were surveyed on the five elements: empathy, reliability, responsiveness, tangible, and assurance. Responsiveness and tangible elements associated with the university's campus, courtyard and library, and assurance. In Malaysia, Hassan et al. (2015) also found a positive and significant relationship between overall EQ skills and teaching effectiveness among 155 lecturers in the public university. Private HEls in Malaysia also sought the same results, which lecturers with a high EQ are found highly confident and committed towards their job (Shah, Saad, Mohan, \& Poniran, 2017). However, only self-regulation and social skills are statistically significant in their study. The study argued that these employees have successfully managed disputes, are excellent communicators and are masters at building and maintaining the relationships.

After carefully analyzing various research studies conducted thus far, these researchers realize that many research works have already been carried out in different service industries such as telecommunication, banking, and insurance. However, only a limited number of empirical studies have been conducted to assess service quality in education, especially in Malaysia. Aims to introduce the concept of using students to measure service quality in tertiary education institutions and set service quality standards from the student's perspective, this study set the following hypothesis: H1: EQ HAS A POSITIVE SIGNIFICANT INFLUENCE ON SERVICE QUALITY.

\subsection{Spiritual Quotient and Service Quality}

While $E Q$ deals with one's emotion, spiritual intelligence $(S Q)$ inspires a person to find a connection to something meaningful that transcends regular day to day actions (Zohar \& Marshall, 2000). SQ benefits the staff and leaders in whichever organization they work for (Saad, See, Adil, \& EQ deals with one's emotion, the spiritual quotient (or intelligence) (SQ) inspires a person to find a connection to something meaningful that transcends regular day to day actions (Zohar \& Marshall, 2000). SQ benefits the staff and leaders in whichever organization they work for (Saad, See, Adil, \& Kassim, 2015; Saad, Hussain, Abdul Rani, \& Abdul Ghani, 2019;) because SQ energizes workplace engagement by mediating work practices in business performance (Saad et al., 2017), employee work's engagement toward organization success (Saad et al., 2019) and increase employee work's contentment leads to better productivity, and commitment (Padigapati \& Chandaraiah, 2020). Vasconcelos (2020) also mentioned that with SQ worker potentially able to make some important contributions to the people that live around and rely on them. SQ is also be defined as the mind's capacity to handle substantial spiritual aspects of personal and professional life that carries meaning for personal, social and academic life (Smith, 2016). Prominent SQ characteristics based on research are projected to be an approach for humankind to transcend all differences in race, culture, and ideology (Menon \& Sadasivan, 2019).

$S Q$ contributes to the capacity to care, tolerate and adapt; to develop a clear and stable sense of individual identity within shifting workplace relationships; to determine the meaning of work and events; to identify and align personal values with a sense of purpose; to live according to one's values; and to understand how ego can sabotage one's values and purposes (Christ-Lakin, 2010). In service quality among nurses and administrative workers also showed that $S Q$ could also enhance a workers' effectiveness and increase their 
work performance (Rani, Abidin \& Hamid, 2013; Saad et al., 2019). The study revealed that only age and education seemed to have positively changed to the relationship. Ahmad, Sulan and Rani (2017) found that when SQ values are implemented at work, they tend to blend harmoniously and work in tandem with the university's growth. In their study, SQ values included a Strong bond with the Creator, Steadfast in upholding shared principles, Creative in making wise decisions, Resolute in facing challenges and Proactive in taking actions. All of these values have helped the selected organizations to perform.

In HEls, the application of SQ values in the organization can improve organizational performance (Attri, 2012). Through the integrity, honesty, respect and connectedness among workers, it can create a good working environment. A recent study showed that in a local public HEls, the students' psychological well-being generally enhances their emotions in a relationship while also showing more positive behaviour and attitude towards others in that relationship (Rani et al., 2017). Students change when their SQ increases as they become calmer and more patient, motivated and focused on academic affairs. Similarly, Pant and Srivastava (2019) also found that SQ relates significantly to mental health among arts and science students. From this, researchers encourage educators to emphasize SQ as a way of approaching students nowadays. All the research studies mentioned above highlight SQ's high impact on individuals in each aspect of performance. Therefore, the following hypothesis is proposed: H2: SQ HAS A POSITIVE AND SIGNIFICANT INFLUENCE ON SERVICE QUALITY.

\subsection{Research Methodology}

The population of interest comprises of all private university lecturers in Selangor, one of the crucial states that must be considered in any research related to private universities in Malaysia. The Ministry of Higher Education reported in May 2018 that Malaysia has 467 private universities in total with the highest number of registered private universities $(29 \%)$ located in the state of Selangor (Kementerian Pendidikan Malaysia, 2018). Therefore, the best population to generalize current research findings would be the lecturers working in Selangor, particularly those in private-owned universities. Using a systematic sampling method, twenty universities were carefully selected for the data collection. The question items for the SQ were adopted-and-adapted from Ayranci (2011). The EQ measurement items were from Goleman (2005), and the service quality performance was from Sureshchandar, Rajendran, and Anantharaman (2002). A 6-point Likert scale was chosen to measure the responses to omit the midpoint. To answer the research questions and hypotheses, this study employs SmartPLS version 3.0. The only limitation for this research is the reluctance of the several institutions to allow their academicians to give any feedback regarding their view on the institutions.

\subsection{Results and Findings}

\subsection{Respondents' Profile}

Descriptive statistics were employed to give an overview of the respondents' profile. A total of 127 responses were received on their profile. There are $38(29.9 \%)$ and $89(70.1 \%)$ men and women respondents. $93(73.2 \%)$ are ethnic Malay participants, $14(11 \%)$ are Chinese and $20(15.7 \%)$ are Indians. The majority of the respondents are between the age of 26 and 35 years old. 86 respondents are married. Most of the respondents ( $43.3 \%$ out of 127 respondents) earn more than RM5,000 a month. Besides, $40.2 \%$ of the respondents have not started a family yet and have, therefore, not employed any house help. $74.8 \%$ of the respondents have a master's degree and work as lecturers with two to five years of teaching experience at the university.

\subsection{Measurement Model Analysis}

Convergent validity refers to the degree to which multiple items assessed have the same concept and are in agreement. The study uses factor loadings, composite reliability (CR) and average variance extracted (AVE) to assess convergent validity as recommended by Hair et al. (2017). The recommended values for the loadings are set at $>0.5$, the AVE should be $>0.5$, and the CR should be $>0.7$. Table 2 shows that this study has conceptualized EQ and $S Q$ as the second-order constructs. Hence, this study follows the repeated indicator approach suggested in the PLS literature to model the second-order factors in the PLS analysis. Table 2 shows that the results of the measurement model exceeded the recommended values, thus indicating sufficient convergence validity (Figure 1).

\begin{tabular}{|c|c|c|c|c|}
\hline \multirow{2}{*}{ First-order constructs } & \multirow{2}{*}{ Second-order construct } & \multirow[b]{2}{*}{ Loadings } & \multirow[b]{2}{*}{ AVE } & \multirow[b]{2}{*}{ CR } \\
\hline & & & & \\
\hline \multirow[t]{3}{*}{ Self-Awareness } & SA2 & 0.806 & 0.656 & 0.851 \\
\hline & SA4 & 0.814 & & \\
\hline & SA5 & 0.809 & & \\
\hline \multirow[t]{4}{*}{ Self-regulation } & SR1 & 0.794 & 0.602 & 0.858 \\
\hline & SR2 & 0.806 & & \\
\hline & SR5 & 0.675 & & \\
\hline & SR6 & 0.821 & & \\
\hline \multirow[t]{4}{*}{ Self-motivation } & SM2 & 0.867 & 0.655 & 0.883 \\
\hline & SM3 & 0.820 & & \\
\hline & SM4 & 0.771 & & \\
\hline & SM5 & 0.775 & & \\
\hline \multirow[t]{2}{*}{ Social Awareness } & SOCA3 & 0.841 & 0.658 & 0.852 \\
\hline & SOCA4 & 0.898 & & \\
\hline
\end{tabular}




\begin{tabular}{|c|c|c|c|c|c|}
\hline \multirow[t]{7}{*}{ Social Skills } & & SS2 & 0.871 & 0.752 & 0.859 \\
\hline & & SS4 & 0.864 & & \\
\hline & Emotional Intelligence (EQ) & Self-Awareness & 0.851 & 0.540 & 0.891 \\
\hline & & Self-regulation & 0.704 & & \\
\hline & & Self-Motivation & 0.831 & & \\
\hline & & Social Awareness & 0.636 & & \\
\hline & & Social Skills & 0.537 & & \\
\hline \multirow[t]{2}{*}{ Grace } & & G1 & 0.905 & 0.746 & 0.854 \\
\hline & & G5 & 0.821 & & \\
\hline \multirow[t]{2}{*}{ Transcendence } & & T3 & 0.882 & 0.752 & 0.858 \\
\hline & & T5 & 0.852 & & \\
\hline \multirow{3}{*}{ Meaning } & & M2 & 0.805 & 0.645 & 0.844 \\
\hline & & M3 & 0.735 & & \\
\hline & & M4 & 0.864 & & \\
\hline \multirow[t]{7}{*}{ Consciousness } & & $\mathrm{C} 2$ & 0.813 & 0.707 & 0.879 \\
\hline & & C3 & 0.837 & & \\
\hline & & C5 & 0.872 & & \\
\hline & Spiritual Intelligence (SQ) & Grace & 0.860 & 0.538 & 0.874 \\
\hline & & Transcendence & 0.698 & & \\
\hline & & Meaning & 0.786 & & \\
\hline & & Consciousness & 0.786 & & \\
\hline
\end{tabular}

After confirming the convergent validity, this study proceeded to evaluate the discriminant validity using the Fornell and Larcker (1981) method. Discriminant validity refers to the degree in which items differentiate among constructs or measure distinct concepts. The criterion employed to evaluate this is by comparing the AVE with the squared correlations or the square root of the AVE with the correlations. This study has used the second method which is to compare the square root of the AVE with the correlations as shown in Table 3. If the square root of the AVE is greater than the values in the row (shown in diagonals) and columns of that particular construct, then it can be concluded that the measures are discriminant. The results in Table 3 indicate that the measures used in this study are distinct and demonstrate adequate discriminant validity.

\begin{tabular}{llccc}
\multicolumn{5}{c}{ Table 3: Discriminant Validity } \\
\hline Constructs & $\mathbf{1}$ & $\mathbf{2}$ & $\mathbf{3}$ \\
\hline 1. & Service Quality & 0.816 & & \\
2. & EQ & 0.589 & 0.735 & \\
3. & SQ & 0.535 & 0.546 & 0.734
\end{tabular}

Notes: Diagonals represent the square root of the AVE, while the off diagonals represent the correlations

The findings underline the important role of service quality at work in this relationship. This study found a positive relationship between EQ and service quality as well as SQ and Service Quality.

\subsection{Structural Model Analysis}

As shown in Figure 1, R2 is calculated to evaluate the structural models' predictive power in this study. R2 denotes the amount of variance explained by the exogenous variables (Barclay et al., 1995). All three variables together explained 41.3 per cent of the variance as illustrated in Figure 1. Using a bootstrapping technique with a re-sampling of 500, the path estimates and t-statistics were calculated for the hypothesized relationships.

Table 4 shows the structural model analysis. From the analysis, it was found that $E Q(\beta=0.423, p<0.05)$ was positively related to Service Quality. SQ $(\beta=0.304, p<0.05)$ was positively related to Service Quality.

\begin{tabular}{lcccc}
\multicolumn{5}{c}{ Table 4: Hypothesis Testing } \\
\hline \multicolumn{1}{r}{ Hypothesis } & Beta & SE & t-value & Decision \\
\hline H1 & & & & \\
EQ $>$ SerQual & 0.423 & 0.110 & 3.841 & Supported \\
H2 & & & & \\
SQ $\rightarrow$ SerQual & 0.304 & 0.111 & 2.734 & Supported \\
\hline Notes: $p<0.05$ & & & &
\end{tabular}




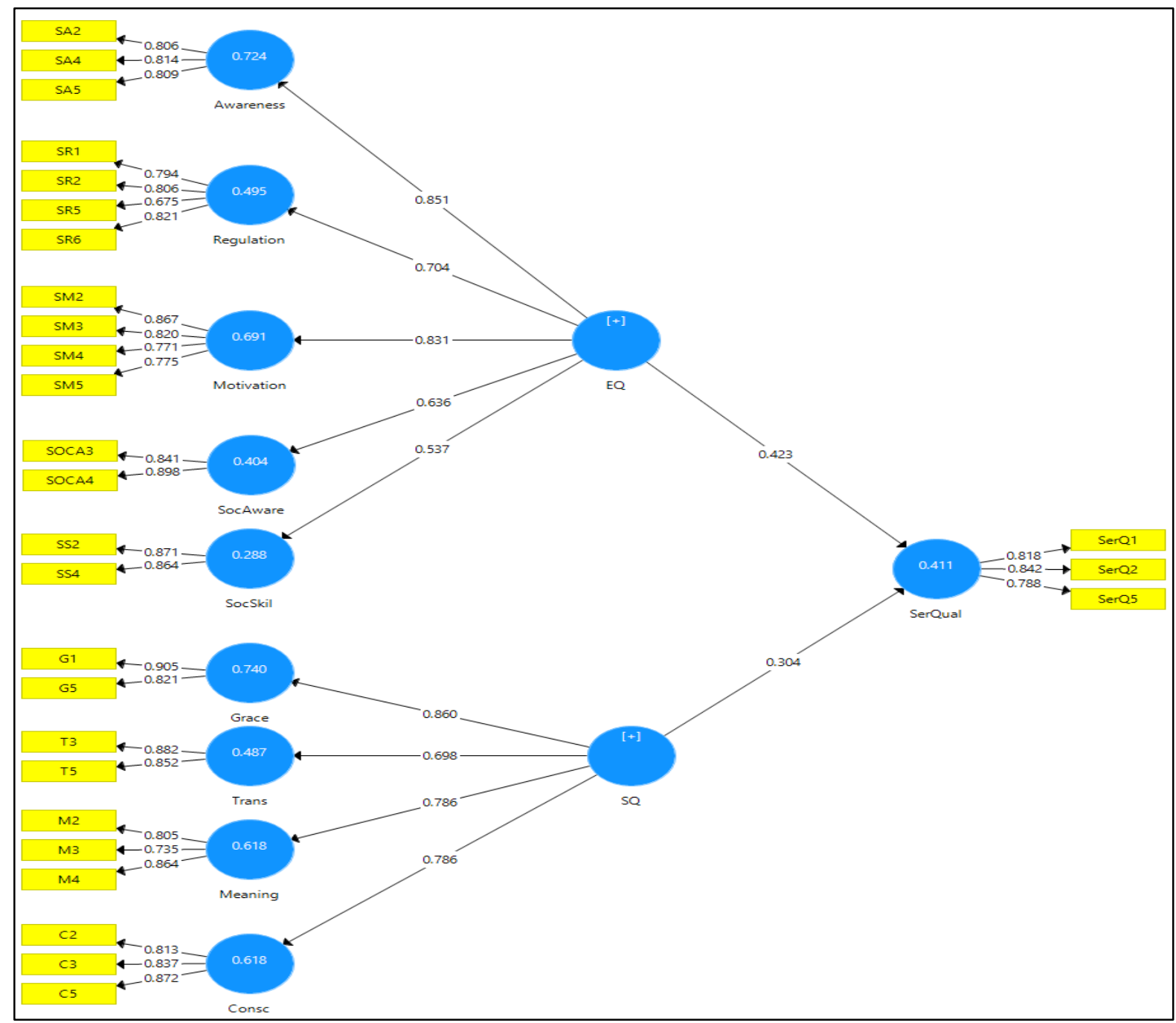

Figure 1: The PLS algorithm results

\subsection{Emotional Quotient on Service Quality}

This study empirically investigated the effects of a lecturer's $E Q$ on service quality in the education industry in the Klang Valley. The findings in the previous section disclose that all $E Q$ dimensions $(\beta=0.423, t=2.841, p<0.05)$ positively affect Service Quality in this study. Our results are consistent with the results of some previous studies that found a positive relationship between $E Q$ and service quality (Opuni \& Adu-Gyamfi, 2015; Hassan et al., 2015; Suifan et al., 2015). According to Opuni and Adu-Gyamfi (2015), a good customer-organization relationship is demonstrated by the personnel's EQ in service delivery. As emphasized by Martins, Ramalho, and Morin (2010), EQ can boost the effectiveness of service delivery. Likewise, perceptions of customers' service quality are directly driven by the extent to which service providers demonstrate $E Q$, which is an outcome of service quality. These arguments are empirically supported by studies done by Opuni and Adu-Gyamfi (2015), Radha and Prasad (2013), Danquah and Weriko (2014), and Shah, Saad, Mohan and Poniran (2017). It indicates that as service providers show a higher EQ level in service delivery, the higher is the quality of services provided. In general, lecturers who have high EQ skills score high on service quality. Furthermore, EQ skills play an essential role in effective teaching and in increasing the teaching performance of the lecturers (Hassan et al., 2015). By obtaining $E Q$, lecturers will enhance service quality as well as academic achievements and personal professional excellence. Hence, lecturers who successfully foster emotional skills and form emotionally intelligent behaviour gain greater success and satisfaction in their professional career and life.

\subsection{Spiritual Quotient on Service Quality}

The correlation coefficient of $S Q$ and its components with service quality $(\beta=0.304, t=2.734, p<0.05)$ indicates a significantly positive correlation between the two variables. This is consistent with the findings of studies by Opuni and Adu-Gyamfi (2015), Javaheri et al. (2013), Danguah (2015), Ramachandran et al. (2017), Shah, Saad, Mohan and Poniran (2017), Saad et al. (2019) and Vasconcelos (2020), which denotes the importance of considering the role of $S Q$ in organizations. It is typical that when a person with a high $S Q$ 
works in an organization with a better service quality, he/she is likely going to be more satisfied with the job. Growing studies on the relationship between these variables indicate the important role of spiritual factors in managing today's organizations. Consequently, managers and top management people try to use their employees' $S Q$ to approach organizational aims. A spiritual workplace environment will directly reduce employees' transfer of jobs, absenteeism, fatigue, and stress, thus influencing employee performance and organizations' overall success. Hence, this study reconfirms that intelligence can boost organizational performance (Attri, 2012; Malik \& Tariq, 2016) and employee's performance (Motakallem, 2014; Saad et al., 2019; Vasconcelos, 2020; Padigapati et al., 2020). The results indicate that lecturers' SQ can directly heighten their service quality level, while a low-level SQ reduces the service quality level somewhat, causing job dissatisfaction and reluctance. This issue should be taken seriously by the top management people to improve the lecturers' perception of their job through job enrichment, empowerment of lecturers, and adding joy to work. Creating a friendly atmosphere based on cooperation instead of competition can increase job satisfaction and a sense of solidarity and unity among the staff which is an investment in any organization. Managers should also be aware of their lecturers' spiritual needs and try to create a dynamic organizational atmosphere. With such measures, it is hoped that lecturers are more satisfied and enjoy doing their daily tasks.

\subsection{Conclusion \& Recommendations}

The integrity of life, intellect, future generations could be preserved through the healthy quality of academicians' life. Overall, this study has found support for the hypothesis that both $S Q$ and $E Q$ are crucial to sustaining academicians' efforts and struggles in delivery expected Service Quality of private university lecturers. The findings reflect on the emergence of the intangible element of intelligence that will help the lecturers cope with existing responsibilities and also achievements in their career. Emotionally and spiritually intelligent lecturers understand their basic roles and responsibilities and can use this intelligence effectively at the workplace which will finally help them become an essential part of the university. The knowledge obtained from this study may provide university policymakers additional insights into emphasizing the development of this intelligence for both the academics and students as they pursue a higher service quality output. The focus could be on professional initiatives like increasing knowledge level, skills, abilities, values, and social assets. Human capital with a strong will is nowadays a very valuable asset for any country and is an essential element in attracting more investments into making Malaysia a great education hub as aspired by the Ministry of Education. Future researchers of such a study must expand this study on a bigger population in reconfirming the findings.

\section{Acknowledgement}

Researchers would like to thank the respondents for their valuable time in answering the questionnaire. Special thanks to International Islamic University Malaysia for funding this publication. In particular, Kulliyyah of Languages and Management for the approval of the main author to attend and present at the conference.

\section{Paper Contribution to Related Field of Study}

This study contributes to filling the gap in the existing literature, which EQ and SQ as factors to the enhancement of the quality of life of the academician in Malaysia.

\section{References}

Ahmad, A., Sulan, N., Rani, A.A., (2017). Integration of Learning Organization Ideas and Islamic Core Values Principle at University, The Learning Organization, ISSN: 0969-6467, p. 392-400.

Ali, A.J. (1992). Islamic Work Ethic in Arabia. Journal of Psychology, 126 (5), 520-607

Attri, R. (2012). Spiritual intelligence: A model for inspirational leadership. Research Journal of Social Science and Management, 1(9), 212-219.

Ayranci, E. (2011). Effects of top Turkish managers' emotional and spiritual intelligence on their organizations' financial performance. Business Intelligence Journal, 4(1), 9-32.

Barclay, D., Higgins, C. \& Thompson, R. (1995). The partial least squares (PLS) approach to causal modelling: personal computer adoption and use as an illustration. Technology Studies, 2(2), 285-309.

Basharat, M.R., \& Raja N.S. (2013). Emotional Intelligence and Service Quality: An Empirical Study of Pakistani Telecommunication Sector. IOSR Journal of Business and Management (IOSR-JBM), 7(6), 18-21.

Boyatzis, E., Goleman, D., \& Rhee, K. (2000). Clustering competence in emotional intelligence: Insights from the Emotional Competence Inventory (ECI). Handbook of Emotional Intelligence, 343-362.

Christ-Lakin, H. (2010). A Correlation Analysis of Transformational Leadership and Spiritual Intelligence. Ph.D. Thesis, University of Phoenix.

Danguah, E. (2015). The effect of emotional intelligence on the financial performance of commercial banks in Ghana: The mediation role of relationship marketing, service quality, customer satisfaction. British Journal of Marketing Studies, 3(2), 8-25. 
Danquah, E., \& Weriko, T.B. (2014). The impact of each element of emotional intelligence on customer service delivery: A customer satisfaction perspective. International Journal of Sales \& Marketing Management Research and Development, 4 (2), 9-20.

Fornell, C. \& Larcker, D.F. (1981). Evaluating structural equation models with unobservable variables and measurement error. Journal of Marketing Research, 18(1), 3950.

George, M. (2006). Practical Applications of Spiritual intelligence in The Workplace. Human Resource Management International Digest, 14 (5).

Goleman, D. (2005). Emotional Intelligence. USA: Bantam Book.

Hair, J.F. Jr, Hult, G.T.M., Ringle, C. \& Sarstedt, M. (2017). A Primer on Partial Least Squares Structural Equation Modeling (PLS-SEM). ${ }^{\text {nd }}$ Ed. Sage Publications, Thousand Oaks, CA.

Hassall, S.L., Muller, J.J. \& Hassal, E.J. (2005) Comparing the Protestant Work Ethic in the Employed Unemployed in Australi. Journal of Economic Psychology, 26, 327341

Hassan, N., Jani, S. H. M., Som, R. M., Hamid, N. Z. A., \& Azizam, N. A. (2015). The relationship between emotional intelligence and teaching effectiveness among lecturers at Universiti Teknologi MARA, Puncak Alam, Malaysia. International Journal of Social Science and Humanity, 5(1), 1-5.

Ishak M.N., Mahmud, Z., \& Ariffin S.R. (2004). Kecerdasan Emosi di Kalangan Pekerja di Malaysia. Laporan Teknikal, Prosiding IPRA 2004, UKM.

Ishak, M.N., Mustapha, R., Mahmud, Z. \& Ariffin, S.N. (2006). Emotional Intelligence of Malaysian Teachers: Implications on workplace productivity. International Journal of Vocational Education and Training, 14, 8-24.

Jain, S., Jain, V., \& Das, S. (2018). Relationship Analysis Between Emotional Intelligence and Service Quality with Special Evidences from Indian Banking Sector. Revista ESPACIOS, 39(33).

Javaheri, H., Safarnia, H., \& Mollahosseini, A. (2013). Survey relationship between spiritual intelligence and service quality. Interdisciplinary Journal of Contemporary Research in Business, 4(9), 547-554.

Kelso R. S. (2008). Measuring undergraduate student perceptions of service quality in higher education. (Unpublished doctoral dissertation). University of South Florida.

Khan, I., \& Singh, N. (2013). A study on gender differences on gratitude, spirituality and forgiveness among school teachers. International Journal of Applied Science and Engineering, 1(1), 9-14.

Malik, M.S. \& Tariq, S. (2016) Impact of Spiritual Intelligence on Organizational Performance. International Review of Management and Marketing, 6 (2) $289-297$.

Martins, A., Ramalho, N., \& Morin, E. (2010). A comprehensive meta-analysis of the relationship between emotional intelligence and health, Journal of Personality and Individual Differences, 49 (6), 554-564.

Mayer, J. D. \& Salovey, P. (1993). Emotional Intelligence and construction of feelings. Applied and Preventive Psychology, 4, $197-208$.

Menon, P. \& Sadasivan, A., (2019) A Vignette of Spiritual Intelligence and Transformational Leadership. International Journal of Innovative Technology and Exploring Engineering, Volume 8, Issue 10, August 2019, 2529-2534.

Motakallem, A. (2014). Role of personality traits and spiritual intelligence in predicting work performance of school principals. International Journal of Basic Sciences \& Applied Research, 3, 14-18.

Opuni, F. F., \& Adu-Gyamfi, K. (2015). An analysis of the impact of emotional intelligence on service quality and customer satisfaction in the Telecommunication Sector in Ghana. International Journal of Sales \& Marketing Management Research and Development, 5(1), $37-52$.

Padigapati, N \& Chandaraiah, K. (2020). The Influence of Spiritual Intelligence on the work-life balance of sales trainer: An empirical research. International Journal of Advanced Science and Technology, 29 (8), 5071-5086.

Pant, N. \& Srivastave, S.K. (2019). The Impact of Spiritual Intelligence, Gender and Educational Background on Mental Health Among College Students. Journal of Religion and Health, Vol. 58, Issue. 1, 87-108.

Radha, S., \& Prasad, N. (2013). A study on customer orientation as between emotional intelligence and service performance in Banks, International Journal of Business and Management Invention, 2(5), 60-66.

Ramachandran, S.D., Krauss, S.E., Hamzah, A. \& Idris, K. (2017). Effectiveness of The Use of Spiritual Intelligence in Women Academic Leadership Practice. International Journal of Education Management, 21 (2), 160-178.

Rani, A.A., Abidin, I. \& Hamid, M.R.A. (2013). The Impact of Spiritual Intelligence on Work Performance: Case Studies in Government Hospitals of East Coast of Malaysia. The Macrotheme Review, 2 (3), 46-59.

Rani, A.A., Hashim, H., Ali, F., Abidin, I. \& Ahmad, A (2017). Inculcating Spiritual Intelligence to Enhance Students' Psychological Wellbeing, International Conference on Education Psychology (ICEEPSY), October 11-14, Porto, Portugal.

Saad, M., See, T.P., Azam, M.A.M., Kassim, N.M. (2015). Spiritual Intelligence on Leadership Effectiveness and Food-Hygiene Practices in Public Institutions. Procedia - Social and Behavioral Sciences, 201, 146-155.

Saad, M., Husain, R., Mahyuddin, M., Ahmad, A., \& Kumarasamy, M.K. (2017). Energizing Workplace Engagement with Spiritual Intelligence. 3rd Asia International Conference (AIC 2017). Paper presented at Universiti Teknologi Malaysia, Kuala Lumpur, 9-10 December 2017. 
Sachro \& Pudjiastuti, S.R. (2013). The effect service quality to customer satisfaction and customer loyalty of Argo Bromo Anggrek Train Jakarta-Surabaya in Indonesia. IOSR Journal of Business and Management (IOSR-JBM), 12(1), 33-38.

Saad, M., R Hussain., Abdul Rani. A., Abdul Ghani, A. (2019). Empowering Employee with Spiritual Intelligence for Higher Quality Food-Hygiene Practices and Food Service Performance of On-premise Caterers. IOP Conference Series: Materials Science and Engineering, Volume 469, Issue 1.

Shah, N. A., Saad, M., Mohan, N.M.M., \& Poniran, H. (2018). Working in private universities: does emotional intelligence matter for job effectiveness? International Journal of Accounting, Finance and Business, 3 (10), 87-96.

Smith, B. (2016). Spiritual Intelligence: definitions and measurements. Fielding Graduate University.

Suifan, T. S., Abdallah, A. B., \& Sweis, R. J. (2015). The effect of a manager's emotional intelligence on employees' work outcomes in the Insurance Industry in Jordan. International Business Research, 8(9), 67-82.

Sureshchandar G.S., Rajendran C., \& Anantharaman R.N. (2002). The relationship between service quality and customer satisfaction-a factor specific approach. Journal of Services Marketing, Vol. 16 No. 4, pp. 363-79.

Vasconcelos, A.F. (2020). Spiritual intelligence: a theoretical synthesis and work-life potential linkages, International Journal of Organizational Analysis, 28 (1).

Yen, N. T. H. (2013). Measuring Service Quality in The Context of Higher Education in Vietnam. Journal of Economics and Development, 15(3), 77-90.

Zohar, D. \& Marshall, I. (2000). Spiritual Intelligence: The Ultimate Intelligence. New York: Scribner 